\title{
Real-time PCR complements immunohistochemistry in the determination of HER-2/neu status in breast cancer Andreea Nistor ${ }^{1}$, Peter H Watson ${ }^{1}$, Norman Pettigrew ${ }^{2}$, Karim Tabiti ${ }^{3}$, Angelika Dawson ${ }^{4}$ and Yvonne Myal*1,5
}

\begin{abstract}
Address: ${ }^{1}$ Department of Pathology, University of Manitoba, 770 Bannatyne Ave., Winnipeg, Manitoba R3E 0W3, Canada, ${ }^{2}$ Department of Pathology, Immunopathology Laboratory, Health Sciences Centre, 820 Sherbrook St., Winnipeg, Manitoba R3A 1A9, Canada, ${ }^{3} \mathrm{Head}$ Alliance Management Oncology, Clinical Genomics, Roche diagnostics GmBH, Nonnenwaldstr. 2, D-82372 Penzberg, Germany, ${ }^{4}$ Department of Biochemistry \& Medical Genetics, University of Manitoba, 770 Bannatyne Ave., Winnipeg, Manitoba R3E 0W3 and the Cytogenetics Laboratory, Health Sciences Centre 820 Sherbrook St., Winnipeg, Manitoba R3A 1A9, Canada and ${ }^{5}$ Molecular Diagnostic Pathology Laboratory, Department of Pathology, Health Sciences Centre, 820 Sherbrook St., Winnipeg, Manitoba R3A 1A9, Canada
\end{abstract}

Email: Andreea Nistor - umnistor@cc.umanitoba.ca; Peter H Watson - pwatson@cc.umanitoba.ca; Norman Pettigrew - pettig@cc.umanitoba.ca; Karim Tabiti - karim.tabiti@roche.com; Angelika Dawson - adawson@hsc.mb.ca; Yvonne Myal* - myal@cc.umanitoba.ca

* Corresponding author

Published: 18 January 2006

BMC Clinical Pathology 2006, 6:2 doi:10.1 186/1472-6890-6-2
Received: 22 August 2005

Accepted: 18 January 2006

This article is available from: http://www.biomedcentral.com/l472-6890/6/2

(C) 2006 Nistor et al; licensee BioMed Central Ltd.

This is an Open Access article distributed under the terms of the Creative Commons Attribution License (http://creativecommons.org/licenses/by/2.0), which permits unrestricted use, distribution, and reproduction in any medium, provided the original work is properly cited.

\begin{abstract}
Background: The clinical benefit of determining the status of HER-2/neu amplification in breast cancer patients is well accepted. Although immunohistochemistry $(\mathrm{IHC})$ is the most frequently used method to assess the over-expression of HER-2 protein, fluorescent in-situ hybridization (FISH) is recognized as the "gold standard" for the determining of HER-2/neu status. The greatest discordance between the two methods occurs among breast tumors that receive an indeterminate IHC score of $2+$. More recently, a real-time polymerase chain reaction (PCR) assay using the LightCycler ${ }^{\circledR}$ has been developed for quantifying HER-2/neu gene amplification. In this study, we evaluated the sensitivity and specificity of a commercially available LightCycler assay as it compares to FISH. To determine whether this assay provides an accurate alternative for the determination of HER-2/neu status, we focused primarily on tumors that were deemed indeterminate or borderline status by IHC.
\end{abstract}

Methods: Thirty-nine breast tumors receiving an IHC score of 2+ were evaluated by both FISH and LightCycler ${ }^{\circledR}$ technologies in order to determine whether quantitative real-time PCR provides an accurate alternative for the determination of HER-2/neu status.

Results: We found a high concordance (92\%) between FISH and real-time PCR results. We also observed that $10 \%$ of these tumors were positive for gene amplification by both FISH and real-time PCR.

Conclusion: The data show that the results obtained for the gene amplification of HER-2/neu by real-time PCR on the LightCycler ${ }^{\circledR}$ instrument is comparable to results obtained by FISH. These results therefore suggest that real-time PCR analysis, using the LightCycler $^{\circledR}$, is a viable alternative to FISH for reassessing breast tumors which receive an IHC score of $2+$, and that a combined IHC and real-time PCR approach for the determination of HER-2 status in breast cancer patients may be an effective and efficient strategy. 


\section{Background}

Gene amplification and over-expression of the HER-2/neu gene, also known as c-erbB-2 or ERBB2, is frequently observed (approximately 25-30\%) in human breast cancer [1]. The HER-2/neu gene, which is a member of the epidermal growth factor receptor (HER) family, is located on chromosome 17q11.2-12 [2] and encodes a $185 \mathrm{kDa}$ transmembrane tyrosine kinase receptor protein.

Considered to play a role in the biologic behavior or pathogenesis of human breast cancer, the amplification of the HER-2/neu gene is now regarded as an established predictive [3] and prognostic [4] marker for breast cancer, particularly for the management of advanced breast cancer. Both node-positive and node-negative breast cancer patients whose tumors exhibit HER-2/neu amplification, have a poor prognosis, an increased risk of recurrence and a high risk of disease-related death showing overall shorter survival rates [5-7,7-10].

However, the major interest in HER-2/neu amplification lies in its utility as a predictive marker of responsiveness to therapy [11] primarily, the response of breast cancer patients to chemotherapy, hormonal therapy (antiestrogens) and therapeutic anti-HER-2 antibodies. Tumors with amplification of this oncogene are less responsive to CMF (cyclophosphamide, methotrexate, and 5-fluorouracil) adjuvant chemotherapy regimens than those with a normal levels of the gene product [12]. Conversely, HER$2 /$ neu amplification is a useful marker to identify the patients who are most likely to benefit from high doses of doxorubicin (Adriamicin) therapy [13-15]. Patients with HER-2/neu gene amplification/over-expression are less responsive to tamoxifen therapy [16-18]. However, the HER-2/neu status is mainly used for identifying patients with advanced breast cancer who may benefit from the therapy with anti-HER-2 antibody trastuzumab/Hercep$\operatorname{tin}^{\circledast}$ (Genetech, San Francisco, CA) a humanized murine monoclonal antibody which has been shown to be effective in prolonging survival in patients with receptor positive metastatic breast carcinoma [19].

While the clinical benefit of determining the status of HER-2/neu amplification/over-expression is clearly accepted, several methods for assessment and quantification of HER-2/neu gene alteration have been used in the search of an accurate, quantitative, widely applicable in clinical setting and cost-effective assay.

Immunohistochemistry (IHC) is most frequently used to assess the over-expression of HER-2 protein. It is an indirect method of measuring gene amplification and is based on the ability of antibodies to identify HER-2 proteins expressed by fixed cells in frozen or paraffin embedded tissue sections. In general, IHC is carried out on paraffin embedded tissues using standard laboratory equipment and therefore is the method of choice for most clinical laboratories. However, IHC analysis relies on subjective interpretation of staining intensity and extent of tumor cells within a section in order to assign an expression score of $0 / 1+$ (regarded as IHC negative) or $2+/ 3+$ (regarded as IHC positive).

Determination of HER-2/neu amplification by Fluorescent in-situ hybridization (FISH) strategies is an alternate method of choice. Whereas IHC detects the over-expression of the HER-2 protein, FISH is a direct method to detect HER-2/neu gene amplification. However, FISH is more time consuming to perform, relatively expensive and requires specialized equipment. Nevertheless, the accuracy of this technique means that FISH assessment is accepted as the "gold standard" for the determination of HER-2/neu status in paraffin embedded breast tumors.

Polymerase chain reaction (PCR)-based assays are able to determine both changes in HER-2/neu gene number and expression [20]. Real-time PCR analysis of DNA offers a precise quantitative analysis of gene amplification. The advantage of this technique is that it is simple, convenient, non-radioactive and rapid so that it is highly suitable for a routine clinical laboratory. No expertise beyond accurate and aseptic pipetting technique is required. However, results from real-time PCR quantitative assays can be affected by contamination of the tumor sample with nucleic acids from non-tumor surrounding tissues. This problem can be reduced by using laser-assisted microdissection, or if not available, by carefully outlining the tumor area on the slide and using only the tumor tissue for analysis.

The evaluation of HER-2/neu status at the mRNA level by reverse-transcription PCR (RT-PCR) has also been proposed $[20,21]$ but the use of formalin-fixed paraffinembedded tissue for this purpose is problematic as the RNA is often extensively degraded. Therefore, the use of RT-PCR is limited to availability of frozen tissue.

Chromogenic in situ hybridization (CISH) is a more recently introduced method for detecting HER-2/neu amplification [22]. CISH makes use of the in situ hybridization technology but also takes advantage of the chromogenic signal detection of IHC. With CISH, a DNA probe is detected using a simple IHC-like peroxidase reaction and positive signals can be detected with the ordinary light microscope. One advantage of CISH is that the assay is one quarter the cost of FISH and can be used when fluorescent microscopy is not available. However CISH, like IHC, relies on subjective interpretation and the utility of some low/high amplified CISH results are sometime in question. 
To date, the FDA has approved two methods [23] for the selection of cancer patients for receiving Herceptin ${ }^{\circledast}$ (Trastuzumab) therapy: IHC and FISH. In practice, both techniques are used in conjunction. IHC assay is used as an initial screening assay to identify clearly negative or positive cases. The FISH assay is then used subsequently in those cases where IHC status is indeterminate $(2+$ IHC positive cases). This sequential strategy avoids the high cost and relatively longer time delay of using the FISH assay in all cases. More recently, a LightCycler HER-2/neu DNA Quantification kit (Roche Molecular Biochemicals, Mannheim, Germany) is currently commercially available and a real-time PCR LightCycler assay has been developed for HER-2/neu evaluation. Advances in PCR technology using the real-time fluorescent monitoring capabilities of the LightCycler have the potential to enable relatively inexpensive, rapid and accurate quantification of gene amplification [24]. The evaluation of the quantitative real time PCR assay for HER2/neu is the focus of this study.

Our objective was to evaluate the specificity and sensitivity of the LightCycler real-time PCR assay as it compares to FISH, focusing primarily on tumors that are indeterminate or borderline HER-2 status by IHC.

\section{Methods \\ Tissue samples}

Between January 2001 and December 2004, 1673 breast tumors were routinely examined by IHC analysis for HER2 protein overexpression at the Immunopathology Laboratory at the Health Science Center, Winnipeg, Manitoba. The tumor samples were fixed, processed and paraffin embedded according to standard protocols [25]. Borderline samples (scored +2 by IHC) consisted of approximately $10 \%$ of the total number of breast tumor samples tested.

Representative Paraffin blocks of 39 randomly selected primary breast tumor samples ranked +2 by IHC were obtained from the Immunopathology Laboratory. FISH and Real-Time PCR analysis were conducted by the Molecular Diagnostic Pathology Laboratory. For real-time PCR analysis, tumor areas with a minimum 100 tumor cells $/ \mathrm{cm}^{2}$ and minimal 'contaminating' normal breast tissue were outlined on the cover glass slip with a permanent marker. The outlined areas were scraped into eppendorf tubes for DNA extraction.

This study was approved by the Pathology Access Committee for Tissues (PACT) and the Research Ethics Board at the University of Manitoba.

\section{Immunohistochemistry (IHC) analysis}

IHC analysis of the HER-2 protein expression was carried out in histologic sections of breast cancer specimens using the HercepTest (DAKO, CA, USA). The HercepTest was approved by the FDA (September, 1988) for selection of women with breast cancer in order to receive trastuzumab humanized monoclonal antibody therapy. Six $\mu \mathrm{m}$ thick tissue sections of the paraffin-embedded blocks were cut, mounted on silane-coated slides, deparaffinized, heattreated for antigen retrieval [26] and immunostained. The heat treatment involved heating in pressure cooker in 10 $\mathrm{mmol} / \mathrm{L}$ citrate buffer for 40 minutes and tissue sections were then cooled. The immunostaining process was carried out using the DAKO Autostainer Universal Staining System according to the instructions of the manufacturer (DAKO, Corp). Briefly, tissue sections were treated with peroxidase-blocking reagent for 5 minutes, rinsed and treated with rabbit anti-human HER-2 primary antibody for 30 minutes. The sections were then rinsed and treated for 30 minutes with secondary goat anti rabbit antibody and horseradish peroxidase and, following rinsing, incubated in diaminobenzidine for 10 minutes. The sections were removed from the Autostainer and counterstained with hematoxylin and mounted in Permount. Membrane staining was interpreted as HER-2 protein overexpression using a bright-field Olympus microscope according to an established scoring system [20] as $0,1+, 2+$ and $3+$ as follows: 0 indicating absence of staining, $1+$ indicating the lowest level of detectable staining and/or non-homogenous weak staining, $2+$ indicating moderate homogenous membrane staining and $3+$ indicating intense homogenous membrane staining. Immunostaining was considered positive when more than $10 \%$ of all cells had $2+$ or $3+$ staining intensity.

\section{FISH analysis}

FISH analysis was carried out using the Vysis LSI HER-2/ neu SpectrumOrange and CEP 17 SpectrumGreen Dual Color DNA probe kit (Vysis PathVysion ${ }^{\circledast}$, Abbot Laboratories, IL) according to the manufacturer's instructions. The locus specific identifier (LSI) HER-2/neu DNA probe is a $190-\mathrm{Kb}$ SpectrumOrange fluorescent-labeled probe that specifically hybridizes to the HER-2/neu gene locus, 17q11.2-q12. The chromosome enumeration probe (CEP) 17 is a $5.4-\mathrm{Kb}$ SpectrumGreen fluorescent labeled DNA probe specific for the alpha satellite DNA sequence at the centromeric region of chromosome 17, 17p11.1q11.1.

HER-2/neu gene copy level was determined by FISH analysis of paraffin-embedded tissue sections as a ratio between the HER-2/neu gene copies and the chromosome 17 centromere copies (Vysis, Inc.). This approach excludes polysomy of chromosome 17 as a source of increased HER-2/neu gene copy number.

The $6 \mu \mathrm{m}$ thick tissue sections on slides were deparaffinized in xylene, followed by dehydration with absolute eth- 
Table I: Comparison of HER-2/neu status assessed by FISH and Real-Time PCR in 39 breast cancer samples deemed 2+ by IHC

\begin{tabular}{|c|c|c|c|c|c|c|}
\hline \multirow[t]{2}{*}{ Sample number } & \multicolumn{4}{|c|}{ FISH } & \multicolumn{2}{|c|}{ Real-Time PCR } \\
\hline & CEP I7 & HER-2 & Ratio & Status & Ratio & Status \\
\hline 1 & 1.83 & 1.83 & 1.00 & - & 1.33 & - \\
\hline 2 & 1.45 & 1.60 & 1.10 & - & 0.48 & - \\
\hline 3 & 1.18 & 1.23 & 1.04 & - & 0.65 & - \\
\hline 4 & 1.35 & 1.27 & 0.94 & - & 1.3 & - \\
\hline 5 & $\mathrm{I} .48$ & 1.75 & 1.18 & - & 1.5 & - \\
\hline 6 & 1.37 & 1.37 & 1.00 & - & 1.74 & - \\
\hline 7 & 2.40 & 3.21 & $\mathrm{I} .34$ & - & 0.66 & - \\
\hline 8 & 1.88 & 1.73 & 0.92 & - & 1.35 & - \\
\hline 9 & 6.22 & 5.85 & 0.94 & - & 1.46 & - \\
\hline 10 & 1.77 & 1.75 & 0.99 & - & 1.62 & - \\
\hline 11 & 1.28 & 1.28 & 1.00 & - & 1.49 & - \\
\hline 12 & 1.72 & 1.68 & 0.98 & - & 1.52 & - \\
\hline 13 & 1.53 & 1.50 & 0.98 & - & 1.42 & - \\
\hline 14 & 1.80 & 1.78 & 0.99 & - & 1.43 & - \\
\hline 15 & 3.30 & 3.22 & 0.98 & - & 1.18 & - \\
\hline 16 & 2.47 & 2.45 & 0.99 & - & 1.59 & - \\
\hline 17 & 1.73 & 1.82 & 1.05 & - & 0.41 & - \\
\hline 18 & 1.70 & 1.73 & 1.02 & - & 1.53 & - \\
\hline 19 & 1.83 & 1.93 & 1.05 & - & 0.35 & - \\
\hline 20 & 3.03 & 3.55 & 1.17 & - & 1.58 & - \\
\hline 21 & 1.97 & 1.55 & 0.79 & - & 1.65 & - \\
\hline 22 & 1.68 & 1.72 & 1.02 & - & 1.60 & - \\
\hline 23 & 1.40 & 1.20 & 0.86 & - & 1.39 & - \\
\hline 24 & 1.27 & 1.80 & 1.42 & - & 1.77 & - \\
\hline 25 & 1.20 & 1.18 & 0.98 & - & 1.68 & - \\
\hline 26 & 1.07 & 1.07 & 1.00 & - & 0.44 & - \\
\hline 27 & 1.10 & 1.08 & 0.98 & - & 0.76 & - \\
\hline 28 & 1.98 & 2.40 & 1.21 & - & 1.49 & - \\
\hline 29 & 1.85 & 2.58 & 1.39 & - & 1.96 & - \\
\hline 30 & 2.70 & 3.22 & 1.19 & - & 1.76 & - \\
\hline 31 & 1.95 & 1.97 & I.0I & - & 1.84 & - \\
\hline 32 & 4.17 & 6.85 & 1.64 & - & 1.67 & - \\
\hline 33 & 1.92 & 2.00 & 1.04 & - & 2.07 & + \\
\hline 34 & 1.77 & 7.13 & 4.03 & + & 1.83 & - \\
\hline 35 & 1.93 & 4.92 & 2.55 & + & $1.5 \mathrm{I}$ & - \\
\hline 36 & 1.92 & 6.77 & 3.53 & + & 3.91 & + \\
\hline 37 & 1.77 & 16.70 & 9.44 & + & 11.10 & + \\
\hline 38 & 2.00 & 5.87 & 2.94 & + & 2.09 & + \\
\hline 39 & 2.00 & 8.15 & 4.08 & + & 2.39 & + \\
\hline
\end{tabular}

CEP $17=$ mean/cell of the chromosome 17 centromere probe signals HER-2 $=$ mean/cell of the HER-2/neu probe signals

FISH Ratio = the ratio between HER-2 and CEP 17

Real-Time PCR Ratio = the normalized ratio between HER-2 and the reference gene (gastrin)

"+" = positive, "-"=negative. Cases (8\%) that were discordant between PCR and FISH assays are highlighted.

anol, air-dried and pre-treated using the Vysis Paraffin Pretreatment Kit I (Vysis, Inc.). Following pre-treatment, the hybridization process was performed at $37^{\circ} \mathrm{C}$ for $14-$ 18 hours (overnight) and the nuclei were then counterstained with 4'-6'-diamidino-2'-phenylindole (DAPI). Enumeration of HER-2/neu and CEP 17 probe signals was performed under fluorescence microscopy with a 100watt mercury lamp at $1000 \mathrm{X}$ magnification using a Zeiss Axiophot fluorescent microscope with triple bands filters.
Scoring was restricted to cancer cells by demarcation of the tumor area on the $\mathrm{H} \& \mathrm{E}$ stained slides by two breast cancer pathologists (PW, WO). In each specimen, 60 nonoverlapping nuclei were counted. The green signals for centromere 17 and the orange signals for HER-2/neu gene were recorded and the ratio calculated for each slide. According to the manufacturer's guidelines, nuclei without signals or only one-color signals or nuclei with insufficient DAPI counter-stain to determine the nuclear 
Table 2: Contingency table showing the breast tumors included in our study categorized according to the cutoff points established for each test (as described in Material and Methods).

\begin{tabular}{ccc}
\hline FISHIPCR & - & + \\
\hline- & 32 & 2 \\
+ & 1 & 4 \\
\hline
\end{tabular}

border were not scored. A ratio of HER-2/neu to chromosome 17 copy number $\geq 2.2$ was considered positive and a ratio $<1.8$ was considered negative for HER-2/neu amplification. The scoring of slides, which presented a ratio between 1.8 and 2.2, was re-evaluated.

\section{Real-Time Quantitative PCR Analysis of HER-2/neu Gene Amplification}

The DNA extraction was performed using the High Pure PCR Template Preparation Kit (Roche).

Real-Time PCR Analysis was performed using the LightCycler (Roche Molecular Biochemicals, Mannheim, Germany) and the LightCycler HER-2/neu Quantification Kit (Roche Molecular Biochemicals, Mannheim, Germany). The gastrin gene was used as the reference housekeeping gene. A 112-bp fragment of the Her-2/neu gene and a 133bp fragment of the gastrin gene were amplified during the PCR reaction. The simultaneously quantification of the HER-2/neu gene and the reference gene that serves both as control for DNA integrity and as a reference for relative quantification was achieved by using different labeled hybridization probes (Red-705 for the HER-2/neu and Red-640 for the gastrin specific oligonucleotide) which allow dual color detection in the same capillary. Five $\mu \mathrm{l}$ (approximately $1 \mu \mathrm{g}$ ) of each sample of the template DNA was mixed with the ready-to-use primers and hybridization probes, enzyme solution (Taq DNA polymerase) and dNTP reaction mix included in the kit in a final volume of $20 \mu \mathrm{l}$. The pre-incubation and denaturation of the template DNA were performed at $95^{\circ} \mathrm{C}$ for 12 minutes. This was followed by amplification of the target DNA through 45 cycles of denaturation at $95^{\circ} \mathrm{C}$ for 10 seconds, annealing at $58^{\circ} \mathrm{C}$ for 10 seconds and elongation at $72^{\circ} \mathrm{C}$ for another 10 seconds. The specimens were then cooled to $40^{\circ} \mathrm{C}$. Samples were analysed in duplicates. The LightCycler HER-2/neu Quantification Kit contained a calibrator DNA provided to generate a calibration curve. The crossing point data for the HER-2/neu and the reference gene were determined and exported into Relative Quantification Software that allowed the calculation of the HER-2/ gastrin normalized ratio. A ratio target gene/reference gene $=2.0$ was considered positive for HER-2/neu gene amplification.

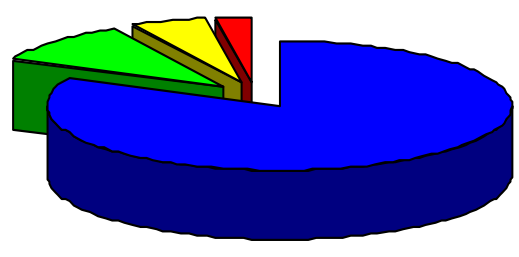

$82 \%$ FISH-/PCR-

口 10\% FISH+/PCR+

口 5\% FISH+/PCR-

$3 \%$ FISH-/PCR+

$+=$ positive

- = negative

Figure I

Concordance between FISH and real-time PCR in IHC 2+ cases $(92 \%)$.

\section{Statistical analysis}

Statistical analysis was performed using GraphPad PRISM $^{\circledast}$, Version 3.02. The concordance between Real Time LyghtCycler PCR and FISH assays were analysed by a Fisher's exact probability test (Table 2), the cut-off point to assign negative and positive status for each method being established as previously described in Material and Methods. The correlation between the two tests was established by calculating the Spearman correlation coefficient.

\section{Results}

As FISH is currently the "gold standard" method for evaluation of HER-2/neu amplification we wanted to examine the performance of the LightCycler Real Time PCR assay as measured against FISH assay in IHC borderline cases. Thirty-nine breast tumor samples that scored 2+ for HER2 protein expression by IHC analysis were selected for this study. Our results (summarized in Table 1) show that of the 39 tumors, 32 (82\%) were scored negative for HER-2/ neu gene amplification and $4(10 \%)$ were scored positive by both PCR and FISH methods, the overall correlation between FISH and real-time PCR results being 92\% (36 of 39 tumors). Of the remaining 3 tumors, 1 was positive by real-time PCR and negative by FISH and 2 were positive by FISH and negative by PCR (Fig. 1).

The results of our study are summarized in the contingency table (illustrated in Table 2) generated by categorizing the results according to the cut-off points described in Material and Methods for each test. Statistical analysis confirmed the $92 \%$ concordance between the HER-2/neu statuses assessed by the 2 methods ( $p<0.0009$, two-sided Fisher's test). The Spearman rank correlation coefficient was $r=0.45$ at $95 \%$ confidence interval $(p=0.0038$, twotailed Spearman correlation).

\section{Discussion}

Thirty percent of breast cancer patients exhibit overexpression of the HER-2 gene and the HER-2/neu status correlates with the response to both specific receptor targeted 
therapy as well as other treatments. It has therefore been recommended that routine screening for HER-2/neu amplification should be performed as part of the evaluation of each new diagnosed case of breast carcinoma [27]. Whereas a lack of assessment of the HER-2/neu status deprives breast cancer patients from beneficial treatment, a false positive diagnosis of gene amplification could lead to an unnecessary expensive therapy with multiple possible side effects, including cardiac dysfunction [28].

In order to establish the best strategy to assess the HER-2/ neu status, numerous studies have compared the results of the two FDA approved assay methods. The discordance between the accuracy of HER-2 protein as determined by IHC and gene amplification as determined by FISH has sparked much debate in the last few years. Some authors have reported a concordance rate as high as $91 \%$ [29] or $88 \%$ [30], but claim a weak concordance between the two methods when the HercepTest score is 2+, such as a $35 \%$ concordance [30]. Similarly, $75 \%$ of the discordant cases (positive by IHC and negative by FISH) had a HercepTest score of $2+[31]$. On the other hand, in a large recently published study [32], only $0.7 \%$ of the IHC negative tumors were found to be positive by FISH and 5.9\% IHC $3+$ tumors were FISH negative so that there was a very good correlation between the HER-2/neu status assessed by FISH and IHC in $0,1+$ as well as $3+$ tumors. Therefore it has been proposed that the $2+$ score, as defined in the guidelines for the FDA-approved HercepTest, should not be used as a criterion for trastuzumab therapy unless confirmed by FISH [33].

Our study was therefore focused predominantly on this borderline 2+ IHC category. Using a real-time PCR quantitative assay, we found a 92\% concordance between FISH and real-time PCR results in breast tumors previously assessed with moderate increased HER-2 protein expression $(2+)$ by IHC. We also found that $10 \%$ of these tumors were positive for gene amplification by both FISH and real-time PCR, and the remaining 90\%, determined to be negative. The high concordance $(92 \%)$ between the FISH and real-time PCR results as well as the discordance between both of these 2 methods with the IHC assay, suggests that real-time PCR is more accurate in determining the patients who are true candidates for trastuzumab therapy. A similarly high concordance between FISH and realtime PCR was previously reported $[34,35]$. In addition, the same authors [34] reported that the observed 92\% concordance rate later increased to $98 \%$ following the incorporation of laser-assisted microdissection into the real time PCR protocol, and they were then able to reclassify the FISH positive, PCR negative specimens to FISH positive, PCR positive.
We also found that two cases negative by FISH, exhibited polysomy of chromosome 17. Interestingly, in these two tumor samples, IHC detected the increased HER-2 protein expression but could not discriminate between true overexpression and polysomy of chromosome 17 . We recognize that polysomy of chromosome 17 can occur in a detectable frequency. Therefore, for quantitative real time PCR assays, consideration should be given to the introduction of a second control gene that is located at a distance away from the amplifiable region and able to detect numerical abnormalities of chromosome 17 . The determination of the copy number of chromosome 17 might be helpful in differentiating breast cancer patients with polysomy of chromosome 17 and those that overexpress the of HER-2 protein and may help identify subgroups of patients that probably have genetic and clinical differences $[21,36]$.

It is also important to note that the prevalence of cancer cells in scraped tissue used for DNA extraction or the inclusion of microdissection strategies, will have an impact on the real-time PCR results. Thus, samples previously deemed PCR negative could be truly PCR positive, when microdissection of the pure tumor tissue was employed.

The results of our present study demonstrate that there can be discordance between the most commonly used assay method (IHC) and other methods of assessing the HER-2 status. Specifically in IHC borderline positive cases, our data suggest that real-time PCR possesses a high potential to enhance accuracy in clinical settings for diagnosis of true trastuzumab therapy candidates. These data need to be confirmed by a larger study as well as a clinical study designed to compare how the HER-2/neu status assessed by FISH and real-time PCR correlates with the response to Herceptin therapy.

\section{Conclusion}

The results obtained by real-time PCR for the amplification of HER-2/neu gene in breast tumors were comparable with results obtained by FISH and suggests that real-time PCR using the LightCycler is a viable alternative to FISH for evaluating tumors deemed indeterminate by IHC. A combined IHC and real-time PCR approach for determining HER-2/neu amplification in breast cancer patients may be an effective and efficient strategy.

\section{Competing interests}

The author(s) declare that they have no competing interests.

\section{Authors' contributions}

Andreea Nistor analyzed the data, carried out statistical analysis and wrote the manuscript. 
Yvonne Myal generated the idea for the study and supervised the study.

Peter Watson provided intellectual input and critically revised the manuscript.

Norman Pettigrew supplied tumor specimens and was responsible for IHC analysis.

Angelika Dawson provided advice and interpretation of FISH analysis.

Karim Tabiti assisted with the interpretation of the LightCycler data.

\section{Acknowledgements}

We would like to acknowledge skilled technical assistance by laboratory technician Ms Renee Fontaine from the Molecular Diagnostics Pathology Laboratory at the Health Science Centre, Winnipeg. We would also like to thank Ms Vicki Brown and Ms Debbie Watson from the Immunopathology Laboratory and Ms Dianne Riordan from the Cytogenetics Laboratory, Health Sciences Centre, Winnipeg, Manitoba. Finally, we also thank Dr. William Orr for the demarcation of tumor areas on paraffin sections of the breast tumor specimens. YM is a Manitoba Medical Services Foundation Career Awardee. This work was supported with funds received from the Health Sciences Research Foundation, Winnipeg. Roche Molecular Biochemicals, Mannheim, Germany provided the real-time PCR kits.

\section{References}

I. Slamon DJ, Godolphin W, Jones LA, Holt JA, Wong SG, Keith DE, Levin WJ, Stuart SG, Udove J, Ullrich A: Studies of the HER-2/neu proto-oncogene in human breast and ovarian cancer. Science 1989, 244:707-7|2.

2. Callahan R: Genetic alterations in primary breast cancer. Breast Cancer Res Treat 1989, 13:191-203.

3. Duffy MJ: Predictive markers in breast and other cancers: a review. Clin Chem 2005, 5 I:494-503.

4. Slamon DJ, Clark GM, Wong SG, Levin WJ, Ullrich A, McGuire WL: Human breast cancer: correlation of relapse and survival with amplification of the HER-2/neu oncogene. Science 1987, 235: $177-182$.

5. Andrulis IL, Bull SB, Blackstein ME, Sutherland D, Mak C, Sidlofsky S, Pritzker KP, Hartwick RW, Hanna W, Lickley L, Wilkinson R, Qizilbash A, Ambus U, Lipa M, Weizel H, Katz A, Baida M, Mariz S, Stoik G, Dacamara P, Strongitharm D, Geddie W, McCready D: neu/erbB2 amplification identifies a poor-prognosis group of women with node-negative breast cancer. Toronto Breast Cancer Study Group. J Clin Oncol 1998, 16:1340-1349.

6. Press MF, Bernstein L, Thomas PA, Meisner LF, Zhou JY, Ma Y, Hung G, Robinson RA, Harris C, el Naggar A, Slamon DJ, Phillips RN, Ross JS, Wolman SR, Flom KJ: HER-2/neu gene amplification characterized by fluorescence in situ hybridization: poor prognosis in node-negative breast carcinomas. J Clin Oncol 1997, 1 5:2894-2904

7. Ro JS, el Naggar A, Ro JY, Blick M, Frye D, Fraschini G, Fritsche H, Hortobagyi G: c-erbB-2 amplification in node-negative human breast cancer. Cancer Res 1989, 49:694I-6944.

8. Paterson MC, Dietrich KD, Danyluk J, Paterson AH, Lees AW, Jamil $\mathrm{N}$, Hanson J, Jenkins $\mathrm{H}$, Krause BE, McBlain WA: Correlation between c-erbB-2 amplification and risk of recurrent disease in node-negative breast cancer. Cancer Res 1991, 51:556-567.

9. Lovekin C, Ellis IO, Locker A, Robertson JF, Bell J, Nicholson R, Gullick WJ, Elston CW, Blamey RW: c-erbB-2 oncoprotein expression in primary and advanced breast cancer. $\mathrm{Br} J$ Cancer I991, 63:439-443.

10. Gullick WJ, Love SB, Wright C, Barnes DM, Gusterson B, Harris AL, Altman DG: c-erbB-2 protein overexpression in breast cancer is a risk factor in patients with involved and uninvolved lymph nodes. BrJ Cancer 199I, 63:434-438.

II. Press MF, Slamon DJ, Flom KJ, Park J, Zhou JY, Bernstein L: Evaluation of HER-2/neu gene amplification and overexpression: comparison of frequently used assay methods in a molecularly characterized cohort of breast cancer specimens. J Clin Oncol 2002, 20:3095-3105.

12. Gusterson BA, Gelber RD, Goldhirsch A, Price KN, Save-Soderborgh J, Anbazhagan R, Styles J, Rudenstam CM, Golouh R, Reed R: Prognostic importance of c-erbB-2 expression in breast cancer. International (Ludwig) Breast Cancer Study Group. J Clin Oncol 1992, 10:1049-1056

13. Muss HB, Thor AD, Berry DA, Kute T, Liu ET, Koerner F, Cirrincione CT, Budman DR, Wood WC, Barcos M: c-erbB-2 expression and response to adjuvant therapy in women with node-positive early breast cancer. $N$ Engl J Med 1994, 330:1260- 1266.

14. Paik S, Bryant J, Park C, Fisher B, Tan-Chiu E, Hyams D, Fisher ER, Lippman ME, Wickerham DL, Wolmark N: erbB-2 and response to doxorubicin in patients with axillary lymph node-positive, hormone receptor-negative breast cancer. I Natl Cancer Inst 1998, 90:1361-1370.

15. Clark GM: Should selection of adjuvant chemotherapy for patients with breast cancer be based on erbB-2 status? J Natl Cancer Inst 1998, 90:| 320-1321.

16. Carlomagno C, Perrone F, Gallo C, De Laurentiis M, Lauria R, Morabito A, Pettinato G, Panico L, D'Antonio A, Bianco AR, De Placido S: c-erb B2 overexpression decreases the benefit of adjuvant tamoxifen in early-stage breast cancer without axillary lymph node metastases. J Clin Oncol 1996, 14:2702-2708.

17. Wright C, Nicholson S, Angus B, Sainsbury JR, Farndon J, Cairns J, Harris AL, Horne $\mathrm{CH}$ : Relationship between c-erbB-2 protein product expression and response to endocrine therapy in advanced breast cancer. $\mathrm{Br} J$ Cancer 1992, 65: II 8- 121 .

18. Pegram MD, Pauletti G, Slamon DJ: HER-2/neu as a predictive marker of response to breast cancer therapy. Breast Cancer Res Treat 1998, 52:65-77.

19. Slamon DJ, Leyland-Jones B, Shak S, Fuchs H, Paton V, Bajamonde A Fleming T, Eiermann W, Wolter J, Pegram M, Baselga J, Norton L: Use of chemotherapy plus a monoclonal antibody against HER2 for metastatic breast cancer that overexpresses HER2. N Engl J Med 200I, 344:783-792.

20. Gjerdrum LM, Sorensen BS, Kjeldsen E, Sorensen FB, Nexo E, Hamilton-Dutoit S: Real-time quantitative PCR of microdissected paraffin-embedded breast carcinoma: an alternative method for HER-2/neu analysis. J Mol Diagn 2004, 6:42-5I.

2I. Vanden Bempt I, Vanhentenrijk V, Drijkoningen M, Wlodarska I, Vandenberghe P, De Wolf-Peeters C: Real-time reverse transcription-PCR and fluorescence in-situ hybridization are complementary to understand the mechanisms involved in HER-2/neu overexpression in human breast carcinomas. Histopathology 2005, 46:43I-44I.

22. Joensuu $H$, Isola J, Lundin M, Salminen T, Holli K, Kataja $V$, Pylkkanen L, Turpeenniemi-Hujanen T, von Smitten K, Lundin J: Amplification of erbB2 and erbB2 expression are superior to estrogen receptor status as risk factors for distant recurrence in pTINOMO breast cancer: a nationwide population-based study. Clin Cancer Res 2003, 9:923-930.

23. Bast RCJ, Ravdin P, Hayes DF, Bates S, Fritsche HJ, Jessup JM, Kemeny N, Locker GY, Mennel RG, Somerfield MR: 2000 update of recommendations for the use of tumor markers in breast and colorectal cancer: clinical practice guidelines of the American Society of Clinical Oncology. J Clin Oncol 200I, 19:1865-1878.

24. Millson A, Suli A, Hartung L, Kunitake S, Bennett A, Nordberg MC, Hanna W, Wittwer CT, Seth A, Lyon E: Comparison of two quantitative polymerase chain reaction methods for detecting HER2/neu amplification. J Mol Diagn 2003, 5: I84-190.

25. Hiller T, Snell L, Watson PH: Microdissection RT-PCR analysis of gene expression in pathologically defined frozen tissue sections. Biotechniques 1996, 21:38-44.

26. Ino $\mathrm{H}$ : Antigen retrieval by heating en bloc for pre-fixed frozen material. J Histochem Cytochem 2003, 5 1:995-1003.

27. Funkhouser WK, Kaiser-Rogers K: Review: significance of, and optimal screening for, HER-2 gene amplification and protein overexpression in breast carcinoma. Ann Clin Lab Sci 200I, 3I:349-358. 
28. Seidman A, Hudis C, Pierri MK, Shak S, Paton V, Ashby M, Murphy M, Stewart SJ, Keefe D: Cardiac dysfunction in the trastuzumab clinical trials experience. J Clin Oncol 2002, 20:1215-122I.

29. Hoang MP, Sahin AA, Ordonez NG, Sneige N: HER-2/neu gene amplification compared with HER-2/neu protein overexpression and interobserver reproducibility in invasive breast carcinoma. Am J Clin Pathol 2000, I I 3:852-859.

30. Kakar S, Puangsuvan N, Stevens JM, Serenas R, Mangan G, Sahai S, Mihalov ML: HER-2/neu assessment in breast cancer by immunohistochemistry and fluorescence in situ hybridization: comparison of results and correlation with survival. Mol Diagn 2000, 5:199-207.

31. Jacobs TW, Gown AM, Yaziji H, Barnes MJ, Schnitt SJ: Specificity of HercepTest in determining HER-2/neu status of breast cancers using the United States Food and Drug Administrationapproved scoring system. J Clin Oncol 1999, 17:1983-1987.

32. Dowsett M, Bartlett J, Ellis IO, Salter J, Hills M, Mallon E, Watters AD, Cooke T, Paish C, Wencyk PM, Pinder SE: Correlation between immunohistochemistry (HercepTest) and fluorescence in situ hybridization (FISH) for HER-2 in 426 breast carcinomas from 37 centres. J Pathol 2003, 199:418-423.

33. Tubbs RR, Pettay JD, Roche PC, Stoler MH, Jenkins RB, Grogan TM: Discrepancies in clinical laboratory testing of eligibility for trastuzumab therapy: apparent immunohistochemical falsepositives do not get the message. J Clin Oncol 200I, 19:27|4-272|.

34. Merkelbach-Bruse S, Wardelmann E, Behrens P, Losen I, Buettner R, Friedrichs $\mathrm{N}$ : Current diagnostic methods of HER-2/neu detection in breast cancer with special regard to real-time PCR. Am J Surg Pathol 2003, 27:1565-1570.

35. Benohr P, Henkel V, Speer R, Vogel U, Sotlar K, Aydeniz B, Reiser A, Neubauer H, Tabiti K, Wallwiener D, Clare SE, Kurek R: Her-2/neu expression in breast cancer--A comparison of different diagnostic methods. Anticancer Res 2005, 25:1895-1900.

36. Salido M, Tusquets I, Corominas JM, Suarez M, Espinet B, Corzo C, Bellet M, Fabregat X, Serrano S, Sole F: Polysomy of chromosome 17 in breast cancer tumors showing an overexpression of ERBB2: a study of 175 cases using fluorescence in situ hybridization and immunohistochemistry. Breast Cancer Res 2005 7:R267-R273.

\section{Pre-publication history}

The pre-publication history for this paper can be accessed here:

http://www.biomedcentral.com/1472-6890/6/2/prepub

\section{Publish with Bio Med Central and every scientist can read your work free of charge}

"BioMed Central will be the most significant development for disseminating the results of biomedical research in our lifetime. "

Sir Paul Nurse, Cancer Research UK

Your research papers will be:

- available free of charge to the entire biomedical community

- peer reviewed and published immediately upon acceptance

- cited in PubMed and archived on PubMed Central

- yours - you keep the copyright
BioMedcentral 